\title{
Microcrustaceans and predators: diel migration in a tropical lake and comparison with shallow warm lakes
}

\author{
Marlene S. Arcifa*, André Perticarrari, Taís C. Bunioto, Andrés R. Domingos and \\ Walter J. Minto
}

Faculdade de Filosofia, Ciências e Letras de Ribeirão Preto, Departamento de Biologia, Universidade de São Paulo, Avenida Bandeirantes, 3900, 14040-901 Ribeirão Preto, São Paulo, Brazil.

* Corresponding author: marcifa@usp.br

Received: 04/05/2015 Accepted: 09/03/2016

\begin{abstract}
Microcrustaceans and predators: diel migration in a tropical lake and comparison with shallow warm lakes

Diel horizontal migration (DHM) and diel vertical migration (DVM) of planktonic microcrustaceans and invertebrate predators were studied simultaneously in a tropical shallow lake. DHM was not performed, and DVM was irregularly performed by the species. DHM of microcrustaceans does not seem to replace DVM as a strategy for decreasing predation risk in this shallow lake. The invertebrate predators, the IV instar of Chaoborus brasiliensis and the water mite Krendowskia sp., were mostly limnetic, the latter undergoing a nocturnal DVM that was not evident for the chaoborid larvae because a portion of the individuals remained in the water column in the daytime. DVM of some microcrustaceans, such as Ceriodaphnia richardi, Daphnia ambigua, Daphnia gessneri, and Thermocyclops decipiens, decreased the overlap with predators. Other behaviours, such as onshore location and occupation of the uppermost layers, seem to be more effective for coping with predation by limnetic invertebrate predators. Dissolved oxygen is a counteracting factor for only the vertical distribution because its concentration is low near the bottom in summer but not in the littoral zone. The lack of DHM in this study agrees with the results of most warm shallow lakes.
\end{abstract}

Key words: Cladocerans, cyclopoids, Chaoborus, water mite, diel migration.

\section{RESUMO}

Microcrustáceos e predadores: migração diária em um lago tropical e comparação com lagos quentes rasos

Foram estudadas, ao mesmo tempo em um lago tropical raso, a migração horizontal diária (MHD) e migração vertical diária (MVD) de microcrustáceos e predadores invertebrados planctônicos. Os microcrustáceos não realizaram MHD e MVD ocorreu irregularmente. MHD não parece substituir MVD como estratégia de microcrustáceos para diminuir o risco de predação nesse lago raso. Os predadores invertebrados, estádio IV de Chaoborus brasiliensis e o ácaro Krendowskia sp., são limnéticos, sendo que este último realiza MVD noturna, menos evidente para as larvas de Chaoboridae, uma vez que uma parte dos indivíduos permanece na coluna de água durante o dia. A MVD de alguns microcrustáceos, como Ceriodaphnia richardi, Daphnia ambigua, Daphnia gessneri e Thermocyclops decipiens, diminuiram a sobreposição com os predadores. Outros comportamentos, como a localização no litoral e a ocupação de estratos superiores da coluna de água, parecem ser mais eficientes face à predação de invertebrados limnéticos. $O$ oxigênio dissolvido é um fator que limita a distribuição vertical, uma vez que sua concentração é baixa perto do fundo no verão, mas não no litoral. A inexistência de MHD neste estudo concorda com resultados obtidos na maioria de lagos quentes rasos.

Palavras-chave: Cladóceros, ciclopoides, Chaoborus, ácaro, migração diária. 


\section{INTRODUCTION}

Light is the proximate cause of diel vertical migration (DVM) and temperature, food and chemical cues act as factors that influence the photoresponse of migrating organisms (review by Haney, 1993). Predation by visual and non-visual predators (Ohman, 1990; Wojtal-Frankiewicz et al., 2010), photodamage (Williamson et al., 2011), growth and reproduction are supposed to be the ultimate causes of DVM.

More recently, diel horizontal migration (DHM) has been suggested as a prey strategy for escaping from predators in shallow temperate lakes (Burks et al., 2002). For avoiding visually oriented pelagic predators, such as fish, prey move to macrophyte stands in the littoral zone during the day. Reverse DHM can be elicited when invertebrate predators, which perform nocturnal DVM, are the major risk. The boundary between the macrophyte stands and the open water can also be a shelter zone for planktonic cladocerans that perform DHM (Lauridsen \& Buenk, 1996). However, these perceived safe habitats in the littoral zone or within the macrophyte stands house other predators. Littoral predators, such as fish and macroinvertebrates (e.g., odonates, notonectids) (González Sagrario et al., 2009), as well as lower food quality (Smiley \& Tessier, 1998), are some of the constraints for organisms that move onshore on a diel cycle.

A recently addressed issue is that DHM may be more effective than DVM as an antipredator defence in shallow lakes due to the lack of a hypolimnetic refuge (Lass \& Spaak, 2003). However, due to higher solar radiation in the tropics, small differences in high temperatures lead to stratification for variable periods with lower stability than in temperate lakes (Lewis, 1996). Therefore, in tropical shallow lakes, in contrast with temperate ones, a hypolimnetic refuge is not always absent, at least in the warm season. The lower number of planktivorous species of fish in the limnetic zone, in (sub)tropical shallow lakes, may decrease the risk of visual predation on zooplankton compared to temperate lakes. Studies and reviews on the feeding habits and spatial distribution of the fish fauna in tropical and subtropical freshwater bodies (Araújo-Lima et al., 1995; Agostinho et al., 2003; Brendonck et al., 2003; Teixeira-de Mello et al., 2009) revealed the predominance of guilds other than planktivory and the littoral zone occupation by most species. The predominance of omnivorous fish in (sub)tropical lakes (Araújo-Lima et al., 1995; Lazzaro, 1997; González-Bergonzoni et al., 2012) leads to a higher predation pressure by invertebrates on the pelagic zooplankton in many low latitude lakes. The reproduction of Chaoborus, one of the most important invertebrate predators, is continuous throughout the year in the tropics (e.g., Cressa \& Lewis, 1984; Arcifa, 1997), resulting in predation pressure for the entire year.

Tropical, subtropical, and warm temperate lakes can differ from temperate ones regarding the costs and benefits of DHM and the use of this strategy to decrease predation risk (e.g., Meerhoff et al., 2006; Tavşanoğlu et al., 2012), which warrants a detailed analysis.

We aimed to evaluate DVM and DHM of planktonic microcrustaceans and invertebrate predators simultaneously, which is rarely attempted in published studies, in a tropical shallow lake. Several studies carried out in the lake on the main zooplankton predators, their distribution and fluctuations (reviewed by Arcifa et al., 2015), their prey and the impact of predation (Castilho-Noll \& Arcifa, 2007a, b) have enabled us to raise hypotheses on the adaptive value of prey behaviours.

Our hypothesis is that DHM is not a prey strategy for decreasing predation risk in this tropical shallow lake.

\section{MATERIALS AND METHODS}

\section{Study area}

Lake Monte Alegre $\left(21^{\circ} 10^{\prime} 04^{\prime \prime} \mathrm{S} ; 47^{\circ} 51^{\prime} 28^{\prime \prime} \mathrm{W}\right)$ is a small, shallow, eutrophic, and warm discontinuous polymictic reservoir located in southeastern Brazil (area 7 ha, $Z_{\max .}=5 \mathrm{~m}$, average depth $=2.9 \mathrm{~m}$ ), inside the campus of the University of São Paulo. Situated at an altitude of $500 \mathrm{~m}$ a.s.l, 
the lake resulted from damming the Laureano Creek, a tributary of the Preto Stream, belonging to the Pardo River basin, in 1942. The source of the creek is $c a .2 .1 \mathrm{~km}$ from the lake, and the catchment areas of Pardo River and Preto Stream basins are $8993 \mathrm{~km}^{2}$ and $325 \mathrm{~km}^{2}$, respectively. It was built for irrigation purposes; however, since the 1980s, it has been used mostly for research and teaching.

Stratification with a defined thermocline established in the warm season can lead to oxygen depletion near the bottom in the deepest area, but not in the littoral zone. Because the outlet is superficial, the dam is not manipulated and the retention time is $c a .45$ days, the lake functions similarly to a natural shallow one, designating it a lake instead of a reservoir. The local climate is tropical semi-humid, with a defined cool-dry season (May-September) and a warm-wet season (October-April).

Macrophytes, mainly the anchored Eichhornia azurea and, more recently, the emergent Ludwigia sp., are distributed in discrete small stands along the lake margins (Meschiatti \& Arcifa, 2002; Souza, 2015). The margins are protected by dense vegetation consisting of trees and grass, preventing a substantial influence on the lake from runoff.

The main limnetic predators of microcrustaceans are the larvae of the dipteran Chaoborus brasiliensis, omnivores that have ontogenetic changes in their diet, increasing the crustaceans' contribution as a dietary item to the III and IV instars (Arcifa, 2000). The limnetic water mite, Krendowskia sp., is less abundant than chaoborid and preys on cladoceran and Chaoborus larvae (Cassano et al., 2002). Littoral predators are odonates, which inhabit macrophyte stands (Meschiatti \& Arcifa, 2002), notonectids and gerrids (Domingos, 2014).

The fish fauna of the lake included 9 species of small- and medium-sized cichlids and characiforms, found mostly within the macrophyte stands (Meschiatti \& Arcifa, 2002). Aquatic insects were the main dietary item of the fish fauna, with zooplankton representing ca. $2 \%$ (Arcifa \& Meschiatti, 1993). The only planktivorous fish is the adult of the exotic cichlid Tilapia rendalli, a pump filter-feeder, which feeds mostly on phytoplankton (Arcifa \& Meschiatti, 1996).

\section{Sampling}

Three sampling series were carried out, two in winter (June and July 2001) and one in summer (March 2002), at daytime (9:00 and 15:00 h) and nighttime (21:00 and 3:00 h), to evaluate the distribution of organisms in two seasons. Three stations were established on a transect in the lake with the following characteristics: station Alocated near the margin, close to the border of a macrophyte stand of Eichhornia azurea, $1 \mathrm{~m}$ deep; station B-located $23 \mathrm{~m}$ from the margin, $3 \mathrm{~m}$ deep; and station C-located ca. $50 \mathrm{~m}$ from the margin, at the centre of the lake, $5 \mathrm{~m}$ deep. Station A will be designated hereafter as littoral, and $\mathrm{B}$ and $\mathrm{C}$, as limnetic.

Two replicates of zooplankton samples $(90 \mathrm{~L}$ each) were taken with a pump (ITT Jabsco, Costa Mesa, USA, model 34600-0000) delivering $30 \mathrm{~L} / \mathrm{min}$ at $0.5 \mathrm{~m}$ at station $\mathrm{A}$; near the surface, 1.5 and $2.5 \mathrm{~m}$ at station $\mathrm{B}$; near the surface, $1.5,2.5$, and $c a .4 \mathrm{~m}$, near the bottom, at station C. The water was filtered through a $60 \mu \mathrm{m}$-mesh net and the organisms were anesthetized with sucrose and fixed with $4 \%$ formalin. Sampling occurred near the border of macrophytes at station A because planktonic microcrustaceans have not been previously found within macrophyte stands.

Three to five sub-samples of $1,2.5$ or $5 \mathrm{~mL}$, taken with Stempel pipettes, were counted for obtaining more than 60 individuals in each sample, to maintain a coefficient of variation lower than 0.20. Samples with low densities, Chaoborus larvae and the water mite Krendowskia sp. were entirely counted.

Temperature, dissolved oxygen (DO), and light intensity were measured during zooplankton samplings using the probe YS model 95 (Yellow Springs, Ohio, USA) and the photometer LI 250 (Li-Cor Inc., Lincoln, Nebraska, USA). Chlorophyll- $a$ (chl- $a$ ) was analysed according to Lorenzen (1967) and the data were transformed into carbon, assuming that chl- $a$ is on average $1.25 \%$ of the algae dry weight, within the range 
given by Reynolds (1984), and C is $50 \%$ of the dry weight.

The mean depth of population (MDP) was used to evaluate the differences between the diurnal (mean of 9:00 and 15:00 h, 2 replicates each) and nocturnal (mean of 21:00 and 3:00 h, 2 replicates each) vertical distribution of the populations in the limnetic zone (stations B and C). The original formula of Worthington (corrected by Pennak, 1943) was used for MDP calculations:

$$
\mathrm{MDP}=\frac{x_{1} d_{1}+x_{2} d_{2}+\cdots}{x_{1}+x_{2}+\cdots}
$$

where $x$ is the density at depth $d$.

As the vertical distribution data failed both normal distribution and homoscedasticity tests, the non-parametric Mann-Whitney $\mathrm{U}$ rank sum test $(N=4$ for day samples and $N=4$ for night ones) was applied for testing the differences between day and night MDP. For the same reasons, non-parametric tests were also used to test differences in the horizontal distribution. After finding that the distribution of individuals in each sampling series for each species did not show any evidence of DHM, samples of all depths at the three stations (A, B, C) and all three sampling series (June, July, March) were pooled by time pe$\operatorname{riod}(N=96$ for day and $N=96$ for night samples), and differences were tested by the MannWhitney $\mathrm{U}$ test. If a significant difference was found $(p \leq 0.05)$ between diurnal and nocturnal samples, it was tested among the stations, in each period of the day ( $N=12$ for $\mathrm{A}, N=36$ for B, and $N=48$ for C), by using the Kruskal-Wallis test. If differences among the three stations were found, the post hoc Dunn test was used to differentiate them.

Spatial overlap between prey and invertebrate predators and between both predators was evaluated by the formula (Williamson \& Stoeckel, 1990):

$$
O_{i j}=\frac{\sum_{z=1}^{m}\left(N_{j z} n_{i z}\right) m}{\sum_{z=1}^{m}\left(N_{j z}\right) \cdot \sum_{z=1}^{m}\left(n_{i z}\right)}
$$

where $z=$ depth, $m=$ number of samples, $N_{j z}=$ density of the predator type $j$ at a given depth, and $n_{i z}=$ density of the prey type $\mathrm{i}$ at a given depth. $O_{i j}=1$ prey and predator are uniformly distributed; $O_{i j}<1$ low overlap; $O_{i j}>1$ high overlap.
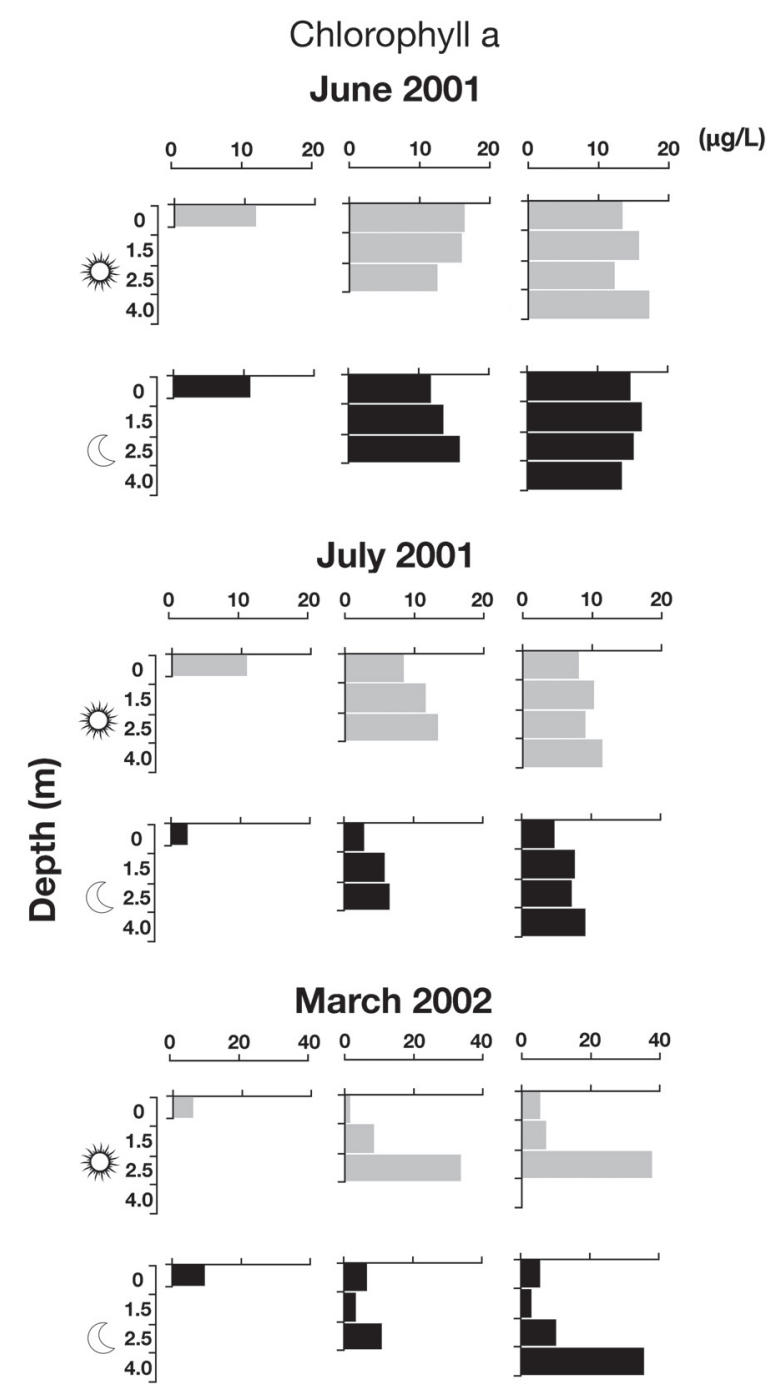

A

B

C

\section{Stations}

Figure 1. Vertical distribution of the concentrations $(\mu \mathrm{g} / \mathrm{L})$ of chlorophyll- $a$ at the three stations (A, B, C), day and night, in the sampling series. Distribuição vertical das concentrações de clorofila-a $(\mu \mathrm{g} / L)$ nas três estações $(A, B, C)$, dia e noite, nas séries de amostragem. 
Table 1. Overlap between the IV instar of Chaoborus and the water mite Krendowskia at stations B and C of the lake, day and night, in two sampling series. $O_{i j}=1$ prey and predator are uniformly distributed; $O_{i j}<1$ low overlap; $O_{i j}>1$ high overlap. Sobreposição entre estádio IV de Chaoborus e o ácaro Krendowskia, nas estações $B$ e $C$ do lago, dia e noite, em duas séries de amostragem. $O_{i j}=1$ presa e predador tem distribuição uniforme; $O_{i j}<1$ menor sobreposição; $O_{i j}>1$ maior sobreposição.

\begin{tabular}{cccccc}
\hline Overlap $\left(O_{i j}\right)$ & & \multicolumn{2}{c}{ Day (h) } & \multicolumn{2}{c}{ Night (h) } \\
\cline { 3 - 6 } IV Instar $\times$ water mite & Station & $9: 00$ & $15: 00$ & $21: 00$ & $3: 00$ \\
\hline July 2001 & C & 0 & 1.66 & 0.82 & 0.97 \\
March 2002 & B & 0 & 1.50 & 0.80 & 0.69 \\
& C & 0 & 0 & 2.57 & 1.37 \\
& B & 0 & 0 & 1.23 & 1.14 \\
\hline
\end{tabular}

Considering all of the overlap values between each species and chaoborid larvae at both sampling times (day and night) and in three sampling series, we calculated the percentage of high overlap values $\left(O_{i j}>1\right)$.

\section{RESULTS}

\section{Physical, chemical, and biological factors}

The lake was weakly stratified in winter (June, July) without a defined thermocline, and temperatures varied from 20 to $23.5^{\circ} \mathrm{C}$ in the water column. Despite the undefined stratification, DO concentrations were relatively low near the bottom, with a mean of $2.5 \mathrm{mg} / \mathrm{L}$. Stratification with a defined thermocline, located between 1.6 and $2.7 \mathrm{~m}$, was established in summer (March 2002), when epi- and hypolimnetic temperatures were $29^{\circ} \mathrm{C}$ and $26.5^{\circ} \mathrm{C}$, respectively. In the limnetic zone, DO concentrations varied from $1.3 \mathrm{mg} / \mathrm{L}$ to $12.5 \mathrm{mg} / \mathrm{L}$ in the deep and surface layers, respectively. DO concentrations were always high in the littoral zone, ranging from 9 to $13.2 \mathrm{mg} / \mathrm{L}$ in the three sampling series.

The euphotic zone extended to the bottom in June $(5 \mathrm{~m})$ but was limited to $3.5 \mathrm{~m}$ in July $(\sim 1.5 \mathrm{~m}$ above the sediment) and $3 \mathrm{~m}$ in March ( $\sim 2 \mathrm{~m}$ above the sediment), coinciding approximately with the upper boundary of the hypolimnion.

The maximum chl- $a$ concentration was higher in summer $(\sim 35 \mu \mathrm{g} / \mathrm{L})$ than in winter $(\sim 13$ to
$15 \mu \mathrm{g} / \mathrm{L})$ (Fig. 1). Chl- $a$ was almost evenly distributed in the water column, except in March, when a deep chl- $a$ maximum near or below the thermocline was observed. Concentrations varied from 3 to $12 \mu \mathrm{g} / \mathrm{L}\left(\sim 0.1\right.$ to $\left.0.5 \mathrm{mgC} \mathrm{L}^{-1}\right)$ in the littoral zone and from 3 to $35 \mu \mathrm{g} / \mathrm{L}(\sim 0.1$ to $1.4 \mathrm{mgC} \mathrm{L}^{-1}$ ) in the limnetic zone in the three sampling series. Concentrations in the deep chla maximum $\left(\sim 35 \mu \mathrm{g} / \mathrm{L}, 1.4 \mathrm{mgC} \mathrm{L}^{-1}\right)$ in March were $c a .9$ times higher than the epilimnetic ones ( $\left.4 \mu \mathrm{g} / \mathrm{L}, 0.16 \mathrm{mgC} \mathrm{L}^{-1}\right)$.

\section{Vertical and horizontal distribution of predators and microcrustaceans}

The species, in general, did not perform DHM, and DVM was irregularly displayed.

The IV instar of Chaoborus brasiliensis performed nocturnal DVM in June and March (Fig. 2). High overlap values were found between chaoborid and mites when the latter was present in the water column (Table 1). The densities were significantly higher in the limnetic zone, at both day and night $(p=0.001)$, with a low number in the littoral zone.

The water mite, Krendowskia sp., showed nocturnal DVM and was predominantly distributed in the limnetic zone (Fig. 2). They occurred in very low densities or were virtually absent in the water column during the day.

The large cladocerans, Daphnia ambigua and D. gessneri, showed significant DVM in June (Fig. 3). In March, both populations remained in a deep layer, on a diel cycle, close or in contact with the deep chl- $a$ maximum layer. Densities of D. gessneri were significantly higher in the limnetic zone than in the littoral zone during the day $(p=0.01)$, with no difference at night. D. ambigua was more abundant in the limnetic zone on a diel cycle $(p=0.001$ and $p=0.03$ for day and night, respectively).

Nocturnal DVM was detected for the mediumsized cladoceran Ceriodaphnia richardi in the three sampling series (Fig. 4). Despite a trend for moving onshore at night, there was no significant difference in densities among the stations.

The small Bosmina tubicen performed reverse DVM in June and nocturnal DVM in July, 


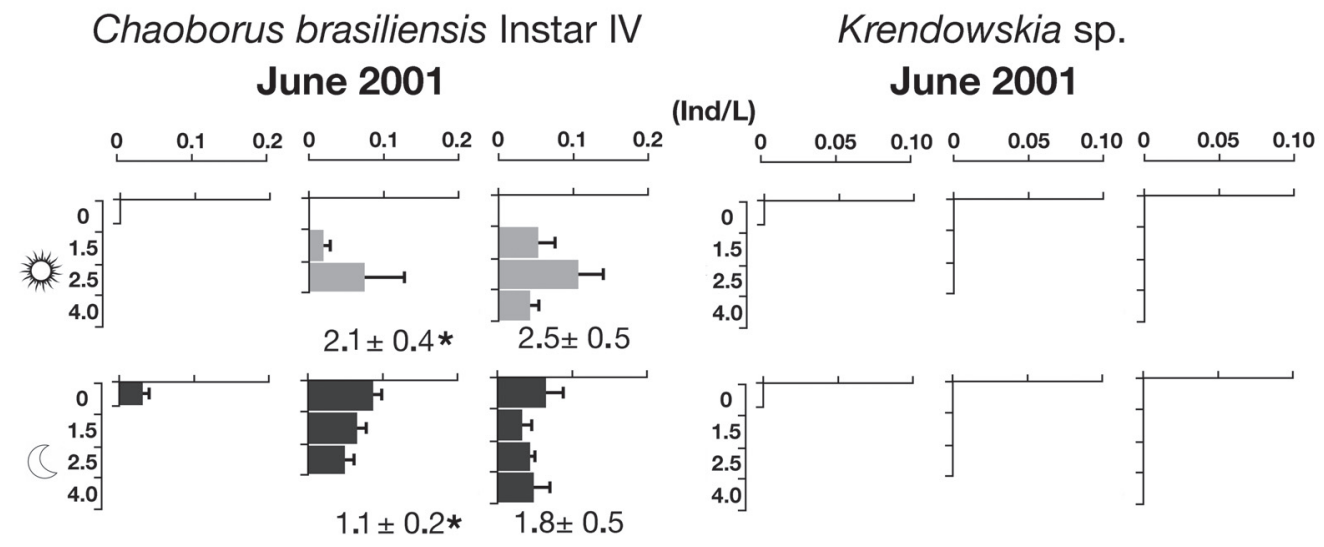

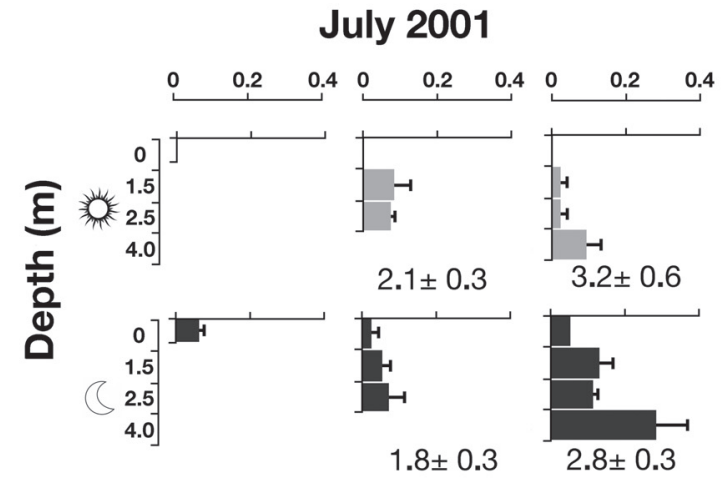

March 2002
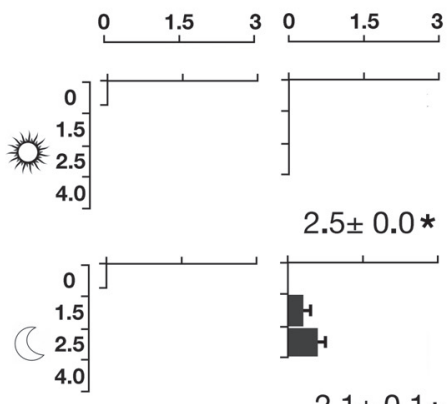

A
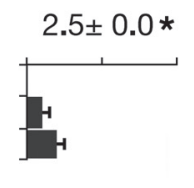

$2.1 \pm 0.1 *$

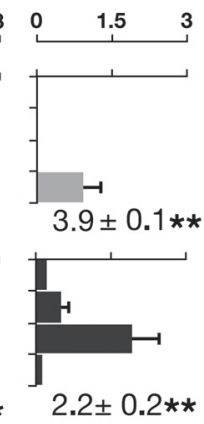

A

C
July 2001

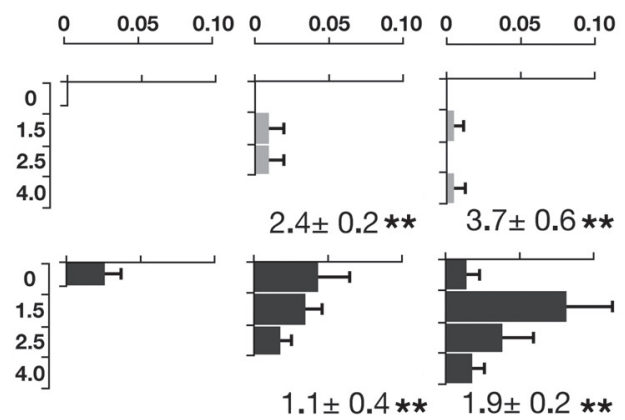

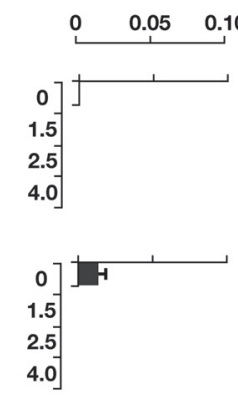

A
March 2002
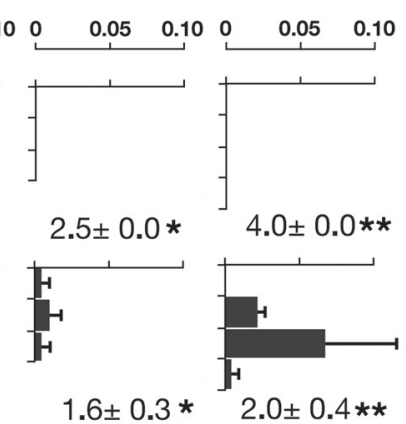

B

C

\section{Stations}

Figure 2. Vertical distribution of the mean densities (ind/L $\pm \mathrm{SE}$ ) of larvae of Chaoborus brasiliensis and the water mite, Krendowskia sp., at the three stations (A, B, C), day and night, in the sampling series. Numbers near bars are the mean depth of population (MDP, in $\mathrm{m} \pm \mathrm{SD}) ; *(p<0.05)$ and $* *(p<0.001)$ indicate significant differences between day and night MDP. Note the different scales used for densities of the species. Distribuição vertical das densidades médias (ind/L \pm EP) de larvas de Chaoborus brasiliensis e de ácaro, Krendowskia sp., nas três estações $(A, B, C)$, de dia e de noite, nas séries de amostragem. Números próximos das barras são a profundidade média da população $(P M P$, em $m \pm D P) ;(\mathrm{p}<0.05) e^{* *}(\mathrm{p}<0.001)$ indicam diferenças significativas entre PMP de dia e de noite. Observe as diferentes escalas utilizadas para as densidades das espécies. 


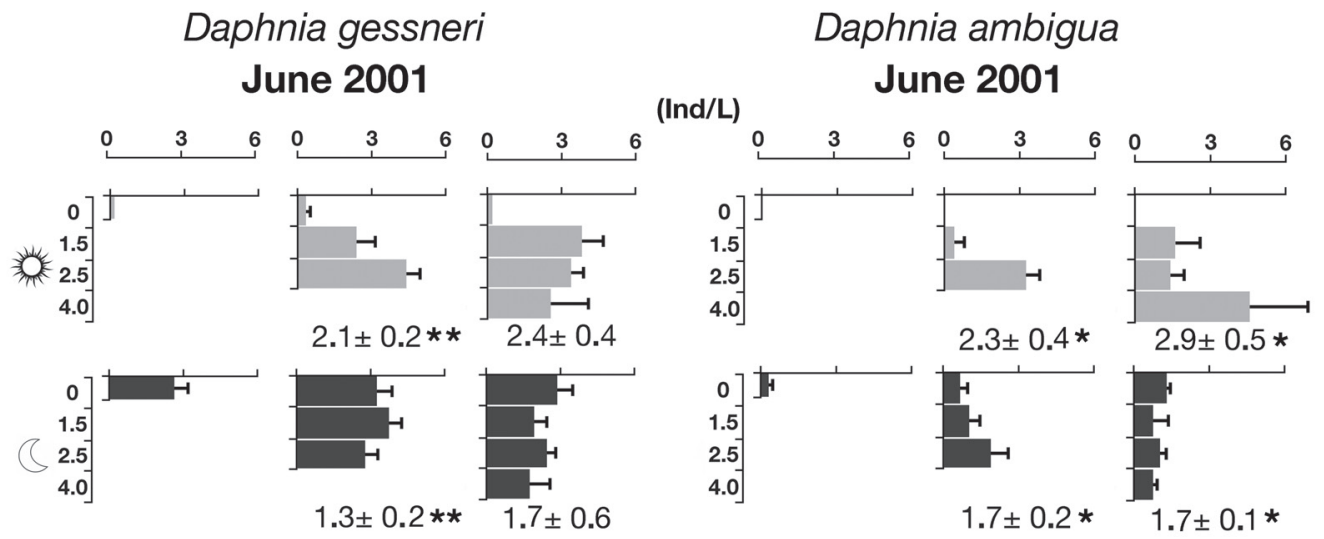

July 2001

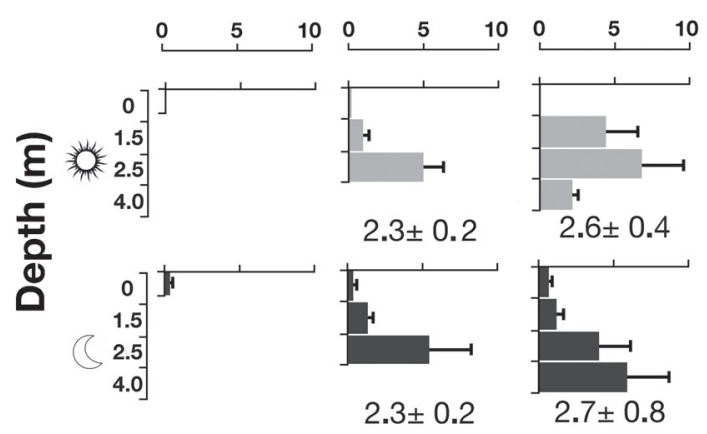

March 2002
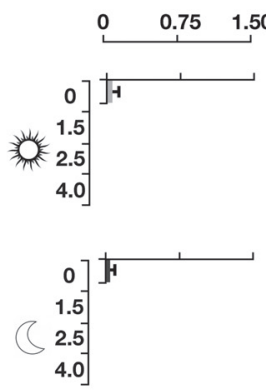

A

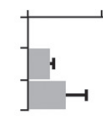

$2.1 \pm 0.5$

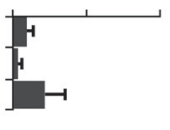

$1.9 \pm 0.7$
$2.7 \pm 0.8$

July 2001

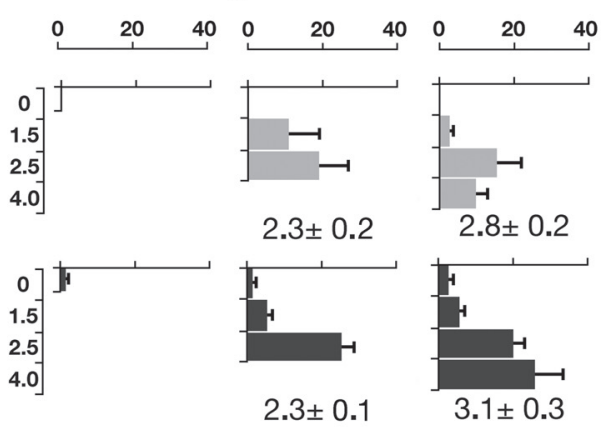

March 2002
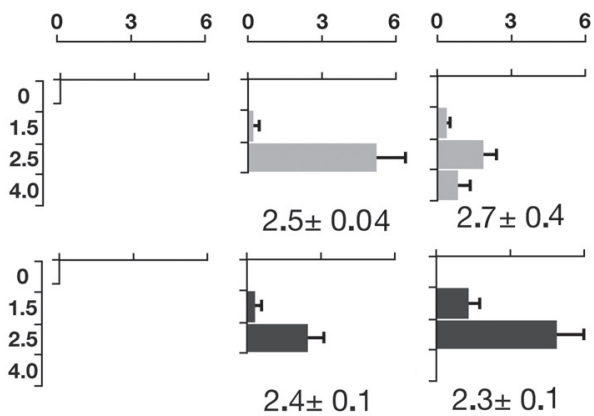

A

$\mathrm{B}$

\section{Stations}

Figure 3. Vertical distribution of the mean densities (ind/L $\pm \mathrm{SE}$ ) of the large-sized cladocerans Daphnia ambigua and D. gessneri at the three stations (A, B, C), day and night, in the sampling series. Numbers near bars are the mean depth of population (MDP, in $\mathrm{m} \pm \mathrm{SD}) ; *(p<0.05)$ and $* *(p<0.001)$ indicate significant differences between day and night MDP. Note the different scales used for densities of the species. Distribuição vertical das densidades médias (ind/L $\pm E P$ ) de cladóceros de tamanho grande Daphnia ambigua $e \mathrm{D}$. gessneri, nas três estações $(A, B, C)$, de dia e de noite, nas séries de amostragem. Números próximos das barras são a profundidade média da população $(P M P$, em $m \pm D P) ; *(\mathrm{p}<0.05)$ e **(p $<0.001)$ indicam diferenças significativas entre PMP de dia e de noite. Observe as diferentes escalas utilizadas para as densidades das espécies. 


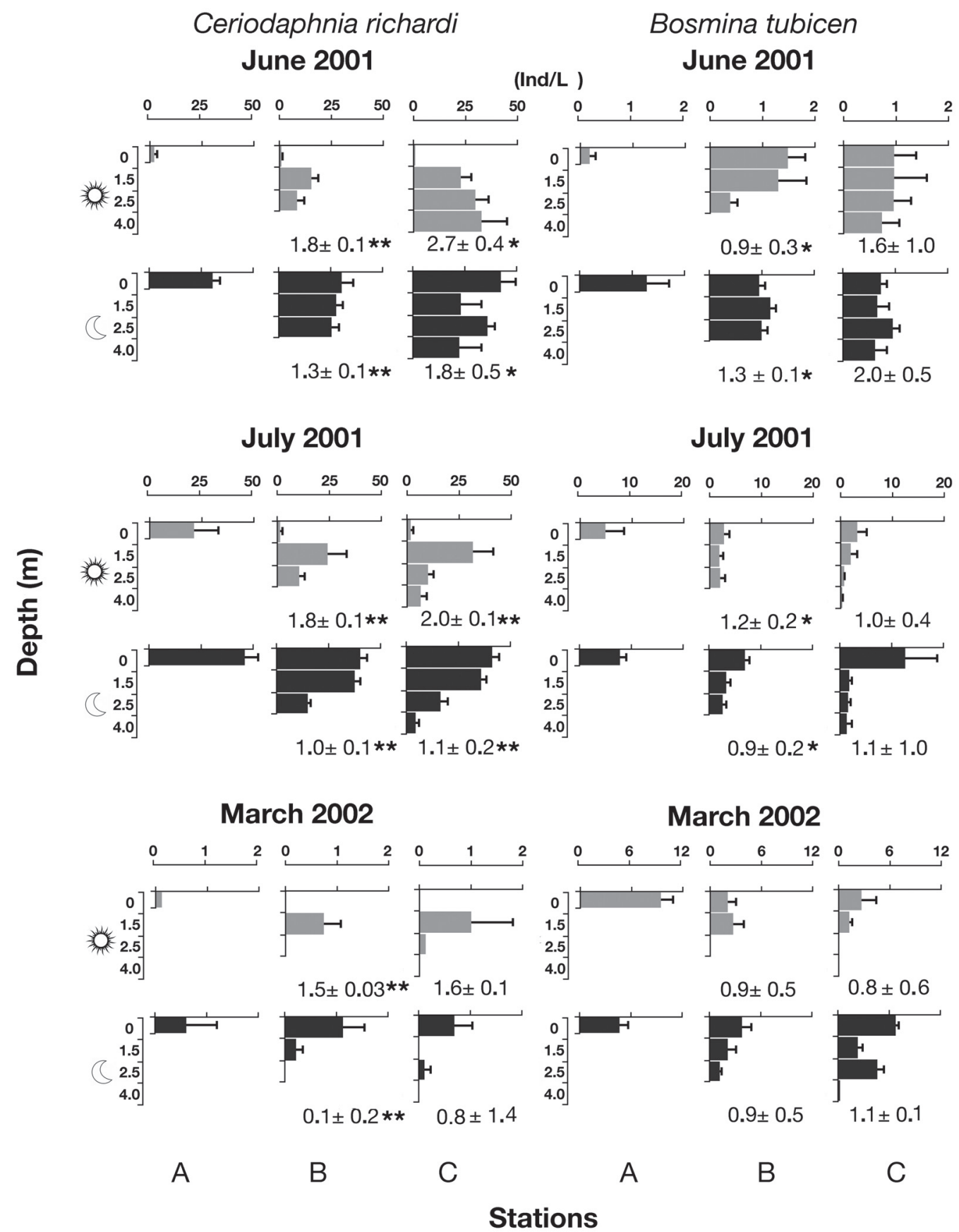

Figure 4. Vertical distribution of the mean densities (ind/L $\pm \mathrm{SE}$ ) of the medium-sized cladoceran Ceriodaphnia richardi and the small-sized Bosmina tubicen at the three stations (A, B, C), day and night, in the sampling series. Numbers near bars are the mean depth of population (MDP, in $\mathrm{m} \pm \mathrm{SD}) ; *(p<0.05)$ and $* *(p<0.001)$ indicate significant differences between day and night MDP. Note the different scales used for densities of the species. Distribuição vertical das densidades médias (ind/L \pm EP) de cladócero de tamanho médio Ceriodaphnia richardi e pequeno Bosmina tubicen, nas três estações $(A, B, C)$, de dia e de noite, nas séries de amostragem. Números próximos das barras são a profundidade média da população $(P M P$, em $m \pm D P) ; *(\mathrm{p}<0.05)$ $e^{* *}(\mathrm{p}<0.001)$ indicam diferenças significativas entre PMP de dia e de noite. Observe as diferentes escalas utilizadas para as densidades das espécies. 
only at station B (Fig. 4). It showed a trend to occupy the top layer, even during the day. Higher densities were found in the littoral zone than in the limnetic zone $(p=0.04$ and $p=0.03$, day and night, respectively).

Another three cladocerans were sampled only in March, with two distributed in the upper layers and the littoral zone. The medium-sized $\mathrm{Di}$ aphanosoma birgei performed nocturnal DVM $(p<0.001)$ within the upper layers and showed higher densities onshore, both during the day and night ( $p=0.02)$. The small-sized Moina micrura showed nocturnal DVM at stations B and C ( $p=0.047$ and $p<0.001$, respectively) in the upper layers, and densities were significantly higher ( $p=0.001)$ in the littoral zone at night than during the day. For the small-sized Ceriodaphnia cornuta, there was no difference in the horizontal distribution, and the population showed nocturnal $\operatorname{DVM}(p=0.03)$.

Copepodites performed DVM in one period (June) (Fig. 5). They were mostly distributed in the limnetic zone, where densities were significantly higher $(p=0.005)$ in both periods of the day than in the littoral zone.

Adults of Tropocyclops prasinus meridionalis did not migrate, except at station $\mathrm{B}$ in March (Fig. 6). They were more abundant at B $(p=0.03)$, during the day, with no significant difference among the stations at night.

Adults of Thermocyclops decipiens showed two DVM patterns, reverse in July and nocturnal in March (Fig. 6). The densities were not significantly different at the stations in both periods of the day.

A feature shared by all species was asynchronous movement of individuals when DVM was performed. The horizontal displacement was shown only by a portion of the population.

When prey performed DVM, overlap values with Chaoborus were usually lower. Prey with lower overall percentages of high overlap values $\left(O_{i j}>1\right)$ with Chaoborus larvae showed a significant preference or a tendency to occupy the littoral zone and the uppermost layers of the water column and performed nocturnal or reverse DVM on some occasions (Table 2). Based on Table 2, prey can be ranked for potential risk by chaoborid predation: $T$. prasinus $>D$. gessneri, D. ambigua $>C$. cornuta $>C$. richardi $>T$. decipiens $>B$. tubicen, D. birgei, M. micrura.
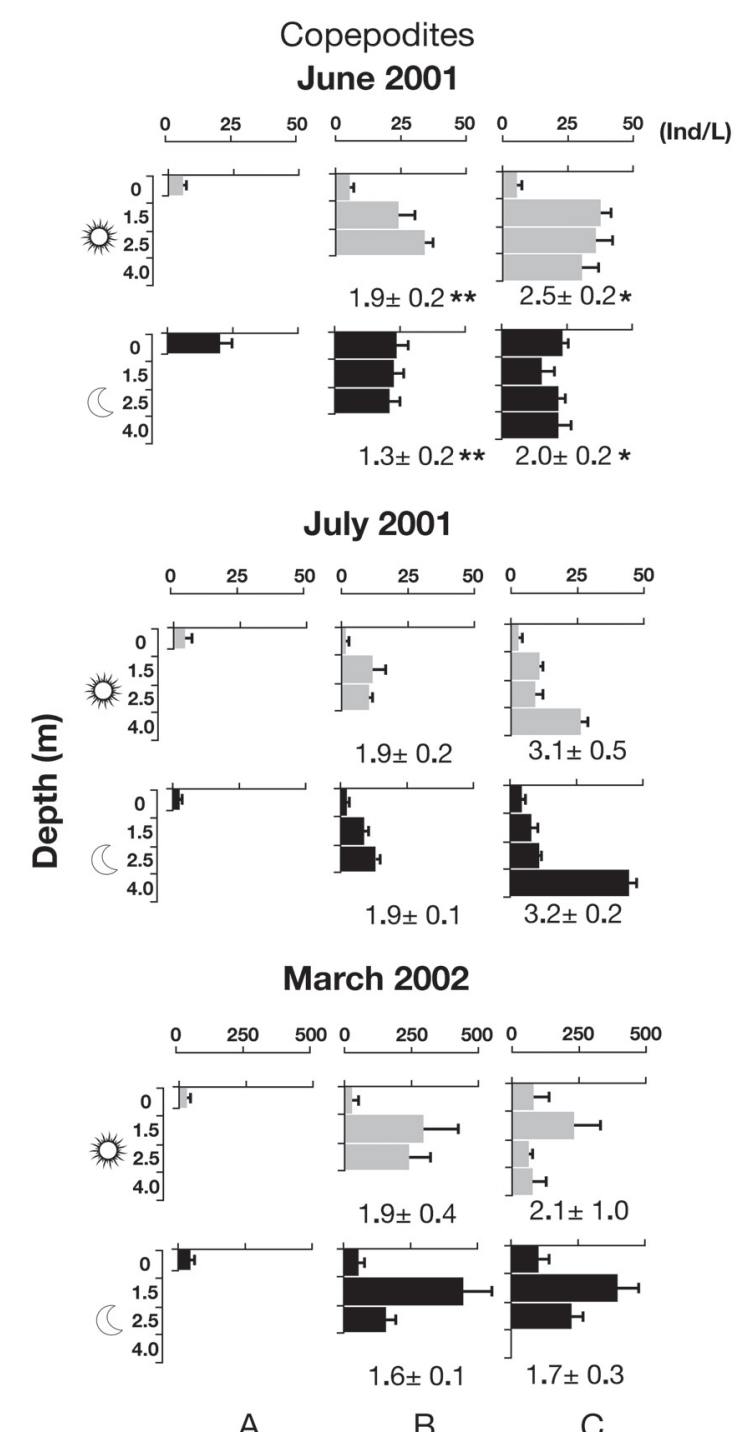

A

\section{Stations}

Figure 5. Vertical distribution of the mean densities (ind/L $\pm \mathrm{SE}$ ) of cyclopoid copepodites at the three stations (A, B, C), day and night, in the sampling series. Numbers near bars are the mean depth of population (MDP, in $\mathrm{m} \pm \mathrm{SD})$; $*(p<0.05)$ and $* *(p<0.001)$ indicate significant differences between day and night MDP. Distribuição vertical das densidades médias (ind/L $\pm E P)$ de copepoditos ciclopoides, nas três estações $(A, B, C)$, de dia e de noite, nas séries de amostragem. Números próximos das barras são a profundidade média da população (PMP, em $m \pm D P) ; *(\mathrm{p}<0.05) e^{* *(\mathrm{p}<0.001)}$ indicam diferenças significativas entre PMP de dia e de noite. 


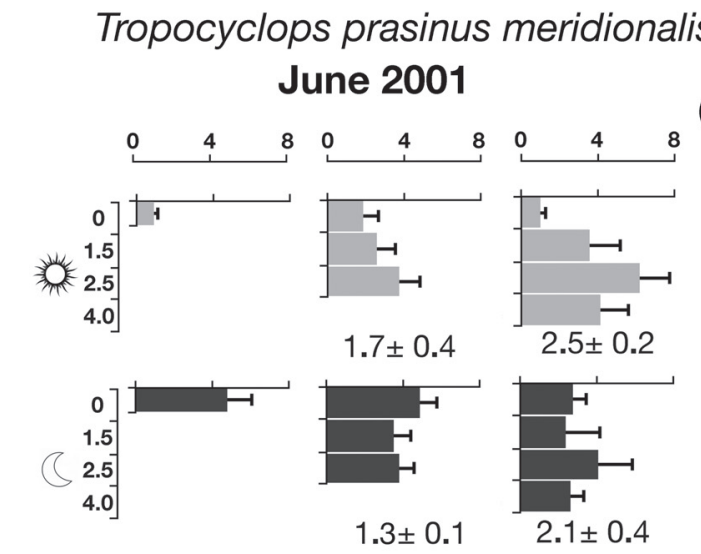

\section{Thermocyclops decipiens June 2001}

(Ind/L)

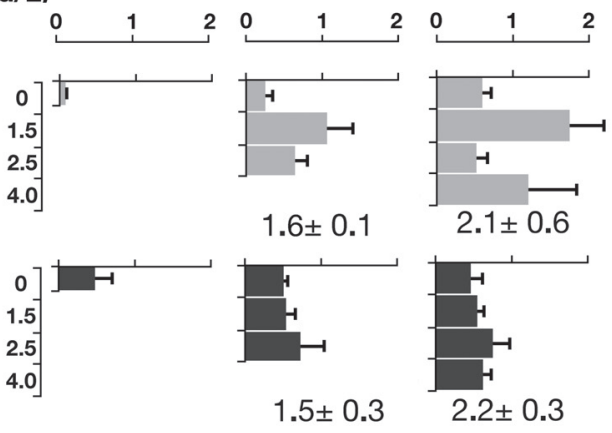

July 2001

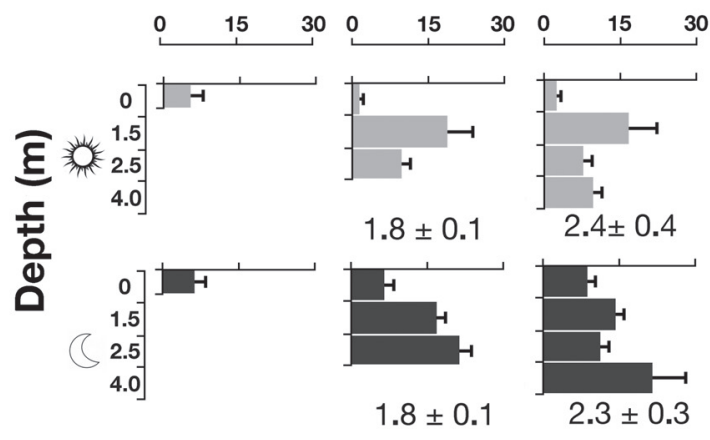

July 2001

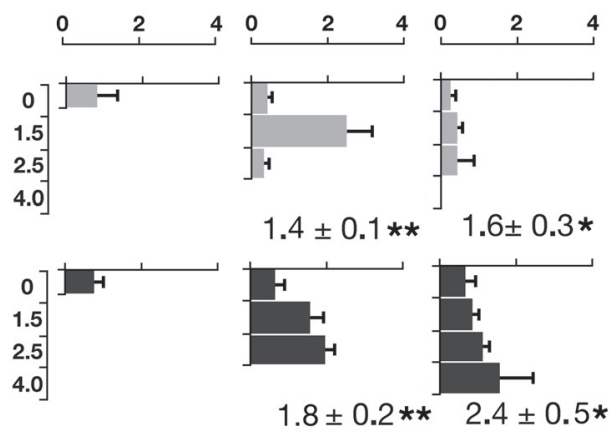

\section{March 2002}

\section{March 2002}
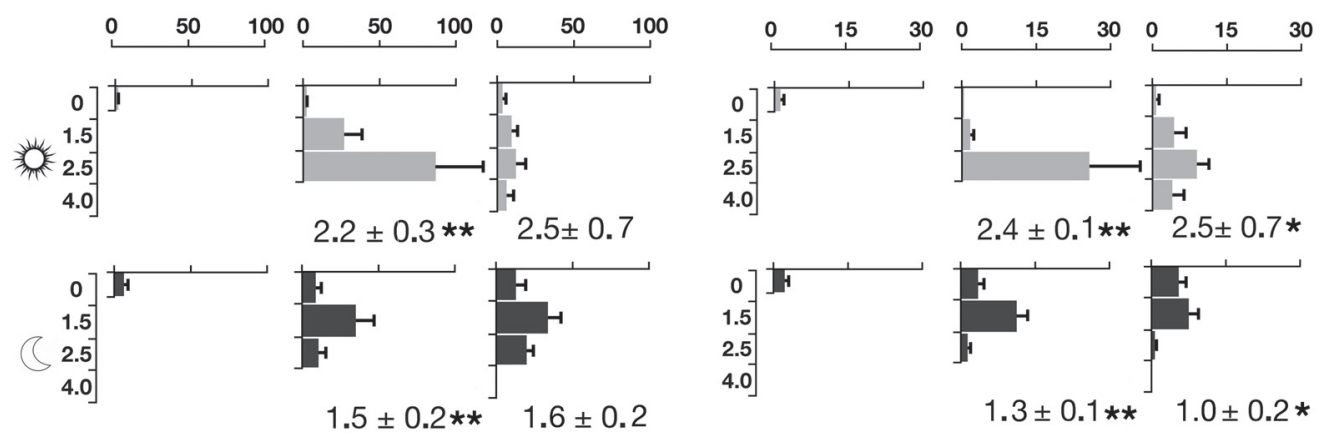

A

$\mathrm{B}$

C

A

B

\section{Stations}

Figure 6. Vertical distribution of the mean densities (ind/L $\pm \mathrm{SE}$ ) of adults of the copepods Thermocyclops decipiens and Tropocyclops prasinus meridionalis at the three stations (A, B, C), day and night, in the sampling series. Numbers near bars are the mean depth of population (MDP, in $\mathrm{m} \pm \mathrm{SD}) ; *(p<0.05)$ and $* *(p<0.001)$ indicate significant differences between day and night MDP. Note the different scales used for densities of the species. Distribuição vertical das densidades médias (ind/L \pm EP) dos adultos dos copépodos Thermocyclops decipiens $e$ Tropocyclops prasinus meridionalis, nas três estações (A, B, C), de dia e de noite, nas séries de amostragem. Números próximos das barras são a profundidade média da população $(P M P$, em $m \pm D P) ; *(\mathrm{p}<0.05)$ $e^{* *}(\mathrm{p}<0.001)$ indicam diferenças significativas entre PMP de dia e de noite. Observe as diferentes escalas utilizadas para as densidades das espécies. 
Table 2. The relative contribution (\%) of high overlap values $\left(O_{i j}>1\right)$ between prey and Chaoborus larvae in increasing order and the main distribution pattern of prey and migratory behaviour, grouped by the entire study period and all sampling times. Abbreviations: lit-littoral, sup-superficial, lim-limnetic, n-nocturnal and r-reverse patterns; superscript number in the DVM = number of sampling series when the crustaceans migrated. A contribuição relativa (\%) dos altos valores de sobreposição $\left(\mathrm{O}_{\mathrm{ij}}>1\right)$ entre presas e larvas de Chaoborus, em ordem crescente, o padrão de distribuição principal da presa e o comportamento migratório, reunindo todo o período de estudo e horários de amostragem. Abreviações: lit-litoral, sup-superficial, lim-limnética, n-noturna e r-reversa; números sobrescritos em MVD = número de períodos de amostragens em que os crustáceos migraram.

\begin{tabular}{|c|c|c|c|c|}
\hline Species & Maximum size (mm) & Percentage of overlap values $>1$ & Main distribution & Migratory behavior \\
\hline D. birgei & 0.60 & 0 & lit, sup & $\mathrm{DVM}^{1}$ \\
\hline M. micrura & 0.50 & 0 & lit, lim, sup & $\mathrm{DVM}^{1}$ \\
\hline B. tubicen & 0.40 & 21 & lit, lim, sup & $\operatorname{DVM}(\mathrm{n}, \mathrm{r})^{2}$ \\
\hline T. decipiens & 0.75 & 37 & lit, lim & $\operatorname{DVM}(\mathrm{n}, \mathrm{r})^{2}$ \\
\hline C. richardi & 0.80 & 42 & lit, lim, sup & $\mathrm{DVM}^{3}$ \\
\hline C. cornuta & 0.40 & 62 & $\lim$ & $\mathrm{DVM}^{1}$ \\
\hline D. ambigua & 0.90 & 75 & $\lim$ & $\mathrm{DVM}^{1}$ \\
\hline D. gessneri & 1.17 & 75 & $\lim$ & $\mathrm{DVM}^{1}$ \\
\hline Copepodites & 0.36 & 79 & $\lim$ & $\mathrm{DVM}^{1}$ \\
\hline T. prasinus & 0.50 & 83 & $\lim$ & $\mathrm{DVM}^{1}$ \\
\hline
\end{tabular}

\section{DISCUSSION}

Our results support the hypothesis that DHM is not a prey strategy for decreasing predation risk in this tropical shallow lake.

The distribution of most chaoborid larvae in the limnetic zone may be adaptive for decreasing predation risk by fish in the littoral zone because they are an important dietary item of juveniles and adults in the lake (Arcifa \& Meschiatti, 1993). However, this distribution does not benefit chaoborid larvae in relation to mite predation as both are limnetic dwellers. The location of a portion of the IV instar larvae in the water column during the day seems to be more adaptive than nocturnal DVM because the potential predatory mite occupies the deepest layer or sediment during the day. Before the detection of mites in 1998, most IV instar larvae migrated to the sediment during the day, virtually disappearing from the water (Arcifa, 1997).

DVM of mites as a strategy for decreasing fish predation is not supported by the data on the fish diet in the lake, where mites are absent (Arcifa \& Meschiatti, 1993) or they contribute a low percentage to the diets of two fish species within macrophyte stands (Meschiatti \& Arcifa, 2002). Riessen (1980) mentions that "water mites are not typically regarded as planktonic organisms". In fact, the erratic and uncoordinated movements of Krendowskia sp. are not typical of a planktonic organism and seem to consume much energy. We may suppose that they move to the water column at night to feed on zooplankton and rest at the bottom during the day to conserve energy.

DVM of both Daphnia species seems to be adaptive regarding predation by both invertebrates because overlap decreased, at least at night. D. gessneri, from Lake Monte Alegre, responded to physical contact with Chaoborus by performing nocturnal DVM in laboratory experiments (Minto et al., 2010). However, as DVM occurred in one of the three sampling series in the lake, we may hypothesise that not migrating and saving energy or exploiting a rich-food layer may be more advantageous.

The preference for the limnetic zone by $D$. ambigua and D. gessneri leads to closer contact with the pelagic invertebrate predators and the planktivorous fish $T$. rendalli. However, their location in the littoral zone the same way as the small- and medium-sized cladoceran species, particularly during the day, may cause a higher mortality imposed by visually oriented predators, such as fish, due to their larger size. Although invertebrate predation on pelagic zooplankton pre- 
vails in the lake, fish predation should not be ruled out when prey adaptive behaviour is taken into account.

The occupation by the medium-sized $D$. birge $i$ and small-sized M. micrura and B. tubicen of the top layer of the water column and the littoral zone, where chaoborid and mites are less abundant, and DVM in this study may be adaptive for decreasing the predation risk by both invertebrate predators.

DVM and location in the uppermost layer at night, resulting in a relatively low overlap with chaoborid larvae, seem to benefit $C$. richardi, a species that has become more frequent and abundant in the lake in recent years.

The lack of DVM and the adoption of both nocturnal and reverse migration by copepods in this study indicate that they are opportunistic and able to change behaviour, as reported in another study (Perticarrari et al., 2004). Copepods switched to reverse DVM in the lake when their contribution to the chaoborid diet increased (Perticarrari et al., 2004). Reverse migration was the response of both copepod species (T. decipiens and T. prasinus) from the lake to kairomones of Chaoborus in laboratory experiments (Minto et $a l ., 2010)$. They have advantages in relation to cladocerans that decreased the impact of chaoborid predation in mesocosm experiments in the lake (Castilho-Noll \& Arcifa, 2007b). Predation pressure on copepods is also lower than on cladocerans in the lake because copepods are not preyed on by mites (Cassano et al. 2002) and are avoided by $T$. rendalli (Arcifa \& Meschiatti, 1996).

Counteracting factors to the distribution of microcrustaceans in the lake may be attributed to DO concentrations and food. In fact, low DO concentrations prevented most organisms from descending to deeper layers in the warm season (March), influencing DVM; the horizontal distribution was not affected by DO because the water column was well oxygenated in the littoral zone. Food concentrations in the littoral zone were above the threshold food concentration $\left(<0.025 \mathrm{mgC} \mathrm{L}^{-1}\right)$ for D. gessneri and $C$. richardi from the lake (Bunioto \& Arcifa, 2007), but cladocerans are sensitive not only to food quantity but also to quality (Fileto et al., 2004). However, laboratory experiments on the influence of seston quantity and quality on two cladoceran species at three stations of the lake (within macrophyte stands, the border of the stands, and the limnetic zone), revealed that food is not the main factor explaining their horizontal distribution (Souza, 2015).

Food requirements for $D$. gessneri are higher than for the smaller $C$. richardi from Lake Monte Alegre (Bunioto \& Arcifa, 2007). We thus hypothesise that food may be more crucial for $D$. gessneri and D. ambigua than for the smaller species. This supports the conclusion that DVM is a flexible strategy, leading to higher food intake by both Daphnia at the expense of increased overlap with predators during summer in the lake. Food and predators can mediate prey response, and the strategy "better dead than unfed" (cited by Haney, 1993) may be a prey choice. As Daphnia is able to find an optimal foraging depth by sensing the food quantity and quality (Jensen $e t$ $a l ., 2001$ ), this ability may explain the location of both Daphnia in a richer food layer during summer in our study.

The temperature difference in the water column $\left(2.5^{\circ} \mathrm{C}\right.$ in summer) during our study was low compared to temperate lakes. Temperature is not a costly factor for vertical migrants in this tropical lake, in contrast to temperate lakes, where additional demographic costs result from greater changes in temperature experienced on a diel cycle (Reichwaldt et al., 2005). Therefore, both Daphnia species were not hampered by temperature, allowing them to take advantage of the chl- $a$ maximum layer.

A conceptual model is presented on predator and prey relationships in the limnetic and littoral zones of the lake and supposedly adaptive prey strategies (Fig. 7). Due to greater fish abundance in the littoral zone, predation on planktonic microcrustaceans should be higher, if they overlap. Prey visibility (size, form, pigmented structures) can be an important component of the choice of these visual predators, with large and more conspicuous prey having disadvantages over small or less visible prey. The invertebrate predators in the littoral zone are represented by 
notonectids and gerrids, which capture prey by sight and mechanoreception (Domingos, 2014). In the limnetic zone, predation is more intense by Chaoborus larvae, which prey on smaller organisms (Bosmina, Ceriodaphnia, young Daphnia), and by mites, which prey on small and large organisms (Bosmina, Daphnia, chaoborid larvae).

We made a compilation of the literature on zooplankton distribution in laboratory and field studies (See Table S1, available at www. limnetica.com). The analysis encompasses only the shallow lakes located at latitudes ranging from $9^{\circ}$ to $41^{\circ}$ in the northern and southern hemispheres and identified as tropical, subtropical, or warm temperate lakes. This review showed that DHM is not a particularly relevant strategy for zooplankton in relation to predation by both vertebrates and invertebrates at lower latitudes.

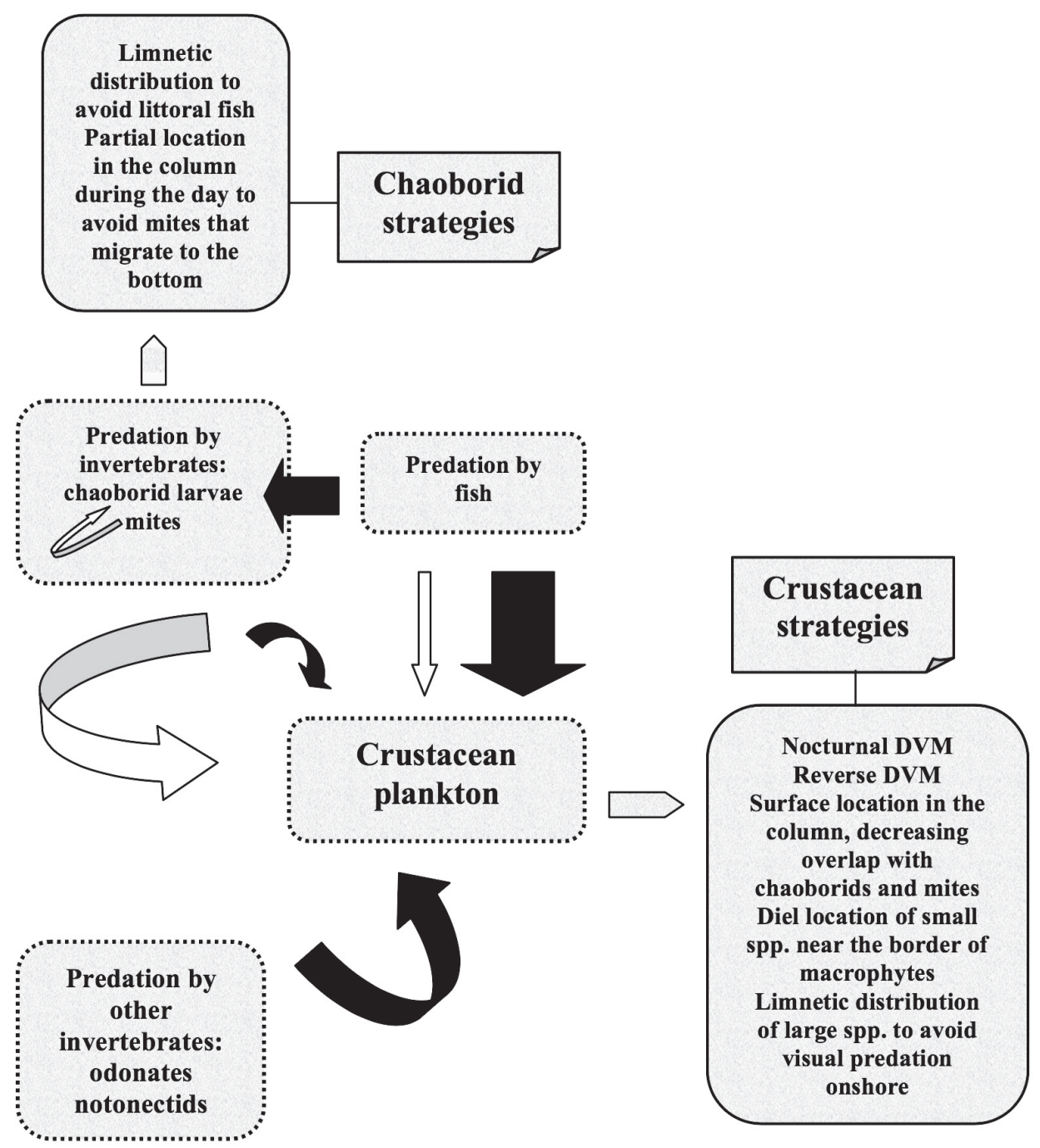

Figure 7. A conceptual model of the interactions among predators and prey and the probable strategies. Dark arrows refer to littoral predation, and white arrows, to limnetic predation. Their widths are proportional to predation intensity. Um modelo conceitual sobre as interações entre predadores e presas e as possíveis estratégias. As flechas escuras referem-se à predação na zona litorânea e flechas brancas à predação na zona limnética e suas larguras são proporcionais à intensidade da predação. (Based on Arcifa \& Meschiatti, 1993, 1996; Arcifa, 2000; Cassano et al., 2002; Meschiatti \& Arcifa, 2002; Perticarrari et al., 2003, 2004; Castilho-Noll \& Arcifa, 2007a; Arcifa et al., 2013; Domingos, 2014; this study). 
Comparing the studies, a stronger deterrent for prey to perform DHM seems to be predation intensity by littoral predators. Apparently, type (floating, submerged, emergent) and abundance of macrophytes do not seem to influence prey behaviour because plants are generally avoided.

In conclusion, microcrustacean species do not appear to perform DHM in Lake Monte Alegre. Therefore, this is not a strategy that replaces DVM for decreasing predation risk in this lake. This conclusion is supported by a study carried out monthly over the course of a year (Arcifa et al., 2013). Our results agree with the data from the warm lakes showing that DHM does not seem to be the main anti-predator strategy. Although DVM was not a regular behaviour, it may be adaptive for coping with predation, in addition to other strategies in the lake. Other behaviours, such as localization onshore and in the upper layers of the water column, seem to be more adaptive for populations of small- and medium-sized species than for populations of large ones. Flexible strategies by microcrustaceans regarding distribution were evident in this study, as well as in previous studies, in this lake and in other ones.

\section{ACKNOWLEDGEMENTS}

We thank the statistician R. C. dos Santos for all of the data analyses, all the people who have helped with the field work, and J. A. Jorge for the loan of equipment. We also thank FAPESP for financial support to MSA (process 97/104076 ) and grants to AP (process 00/12730-3) and TCB (process 01/01150-9) and two anonymous reviewers for their valuable suggestions.

\section{REFERENCES}

AGOSTINHO, A. A., L. C. GOMES \& H. F. JÚLIOJÚNIOR. 2003. Relações entre macrófitas aquáticas e fauna de peixes. In: Ecologia e manejo de macrófitas aquáticas. S. M. Thomaz \& L. M. Bini (eds.): 261-279. EDUEM, Maringá, Brasil.

ARAÚJO-LIMA, C. A. R. M., A. A. AGOSTINHO \& N. FABRÉ. 1995. Trophic aspects of fish commu- nities in Brazilian rivers and reservoirs. In: Limnology in Brazil. J. G. Tundisi, C. E. M. Bicudo \& T. M. Tundisi (eds.): 105-136. ABC/SBL, Rio de Janeiro, Brasil.

ARCIFA, M. S. 1997. Fluctuations and vertical migration of Chaoborus in a tropical Brazilian reservoir: Lake Monte Alegre. Acta Limnologica Brasiliensia, 9: 93-103.

ARCIFA, M. S. 2000. Feeding habits of Chaoboridae larvae in a tropical Brazilian reservoir. Revista Brasileira de Biologia = Brazilian Journal of Biology, 60: 591-597.

ARCIFA, M. S. \& A. J. MESCHIATTI. 1993. Distribution and feeding ecology of fishes in a Brazilian reservoir: Lake Monte Alegre. Interciencia, 18: 302-313.

ARCIFA, M. S. \& A. J. MESCHIATTI. 1996. Tilapia rendalli in the Lake Monte Alegre, a case of planktivory. Acta Limnologica Brasiliensia, 8: 221-229.

ARCIFA, M. S., T. C. BUNIOTO, A. PERTICARRARI \& W. J. MINTO. 2013. Diel horizontal distribution of microcrustaceans and predators throughout a year in a shallow neotropical lake. Brazilian Journal of Biology, 73: 103-114.

ARCIFA, M. S., T. C. S. FERREIRA, C. FILETO, M. S. M. CASTILHO-NOLL. T. C. BUNIOTO \& W. J. MINTO. 2015. A long-term study on crustacean plankton of a shallow tropical lake: the role of invertebrate predation. Journal of Limnology, 74: 606-617.

BRENDONCK, L., J. MAES, W. ROMMENS, N. DEKEZA, T. NHIWATIWA, M. BARSON, V. CALLEBAUT, C. PHIRI, K. MOREAU, B. GRATWICKE, M. STEVENS, N. ALYN, E. HOLSTERS, F. OLLEVIER \& B. MARSHALL. 2003. Impact of water hyacinth (Eichhornia crassipes) in a eutrophic subtropical impoundment (Lake Chivero, Zimbabwe). II. Species diversity. Archiv für Hydrobiologie, 158: 389-405.

BUNIOTO, T. C. \& M. S. ARCIFA. 2007. Effects of food limitation and temperature on cladocerans from a tropical Brazilian lake. Aquatic Ecology, 41: 569-578.

BURKS, R. L., D. M. LODGE, E. JEPPESEN \& T. L. LAURIDSEN. 2002. Diel horizontal migration: costs and benefits of inhabiting the littoral. Freshwater Biology, 47: 343-365.

CASSANO, C. R., M. S. M. CASTILHO-NOLL \& M. S. ARCIFA. 2002. Water mite predation on zooplankton of a tropical lake. Brazilian Journal of Biology, 62: 565-571. 
CASTILHO-NOLL, M. S. M. \& M. S. ARCIFA. 2007a. Chaoborus diet in a tropical lake and predation of microcrustaceans in laboratory experiments. Acta Limnologica Brasiliensia, 19: 163174.

CASTILHO-NOLL, M. S. M. \& M. S. ARCIFA. 2007b. Mesocosm experiment on the impact of invertebrate predation on zooplankton of a tropical lake. Aquatic Ecology, 41: 587-598.

CASTRO, B. B., S. M. MARQUES \& F. GONÇALVES. 2007. Habitat selection and diel distribution of the crustacean zooplankton from a shallow Mediterranean lake during the turbid and clear water phases. Freshwater Biology, 52: 421-433.

CRESSA, C. \& W. M. LEWIS Jr. 1984. Growth and development patterns in a tropical Chaoborus species and their ecological significance. Archiv für Hydrobiologie, 100: 21-28.

DOMINGOS, A. R. 2014. Distribuição espacial de insetos aquáticos (Hemiptera: Notonectidae e Gerridae) e a influência sobre a comunidade zooplanctônica do Lago Monte Alegre. Master's Thesis. Universidade de São Paulo, Brasil.

FANTIN-CRUZ, I., K. K. TONDATO, J. M. F. PENHA, L. A. F. MATEUS, P. GIRARD \& R. FANTIN-CRUZ. 2008. Influence of fish abundance and macrophyte cover on microcrustacean density in temporary lagoons of the Northern Pantanal-Brazil. Acta Limnologica Brasiliensia, 20: 339-344.

FILETO, C., M. S. ARCIFA, A. S. FERRÃO-FILHO $\&$ L. H. S. SILVA. 2004. Influence of phytoplankton fractions on growth and reproduction of tropical cladocerans. Aquatic Ecology, 38: 503-514.

GONZÁLEZ-BERGONZONI, I., M. MEERHOFF, T. A. DAVIDSON, F. TEIXEIRA-DE MELLO, A. BAATTRUP-PEDERSEN \& E. JEPPESEN. 2012. Meta-analysis shows a consistent and strong latitudinal pattern in fish omnivory across ecosystems. Ecosystems, 15: 492-503.

GONZÁLEZ SAGRARIO, M. A., E. BALSEIRO, R. ITUARTE \& E. SPIVAK. 2009. Macrophytes as refuge or risky area for zooplankton: a balance set by littoral predacious macroinvertebrates. Freshwater Biology, 54: 1042-1053.

GONZÁLEZ SAGRARIO, M. A. \& E. BALSEIRO. 2010. The role of macrophytes and fish in regulating the provision by macrophytes of refugia for zooplankton in a warm temperate lake. Freshwater Biology, 55: 2153-2166.
HANEY, J. F. 1993. Environmental control of diel vertical migration behaviour. In: Diel vertical migration of zooplankton. J. Ringelberg (ed.): 1-17. Archiv für Hydrobiologie Beihefte Ergebnisse der Limnologie, 39.

IGLESIAS, C., G. GOYENOLA, N. MAZZEO, M. MEERHOFF, E. RODO \& E. JEPPESEN. 2007. Horizontal dynamics of zooplankton in subtropical Lake Blanca (Uruguay) hosting multiple zooplankton predators and aquatic plant refuges. $\mathrm{Hy}$ drobiologia, 584: 179-189.

JENSEN, K. H., P. LARSSON \& G. HÖGSTED. 2001. Detecting food search in Daphnia in the field. Limnology and Oceanography, 46: 1013-1020.

KEPPELER, E. C. 2003. Abundance of zooplankton from different zones (pelagic and littoral) and time periods (morning and night) in two Amazonian meandering lakes. Acta Scientiarum, Biological Sciences, 25: 287-297.

LASS, S. \& P. SPAAK. 2003. Chemically induced anti-predator defences in plankton: a review. Archiv für Hydrobiologie, 491: 221-239.

LAURIDSEN, T. L. \& I. BUENK. 1996. Diel changes in the horizontal distribution of zooplankton in the littoral zone of two shallow eutrophic lakes. Archiv für Hydrobiologie, 137: 167-176.

LAZZARO, X. 1997. Do the trophic cascade hypothesis and classical biomanipulation approaches apply to tropical lakes and reservoirs? Verhandlungen der Internationale Vereinigung für Limnologie, 26: 719-730.

LEWIS, W. M. Jr. 1996. Tropical lakes: how latitude makes a difference. In: Perspectives in tropical limnology. F. Schiemer \& K. T. Boland (eds.): 43-64. SPB Academic Publishing bv., Amsterdam, Netherlands.

LORENZEN, C. J. 1967. Determination of chlorophyll and phaeo-pigments: Spectrophotometric equations. Limnology and Oceanography, 12: 343-346.

MEERHOFF, M., C. FOSALBA, C. BRUZZONE, N. MAZZEO, W. NOORDOVEN \& E. JEPPESEN. 2006. An experimental study of habitat choice by Daphnia: plants signal danger more than refuge in subtropical lakes. Freshwater Biology, 51: 13201330.

MEERHOFF, M., C. IGLESIAS, F. TEIXEIRA-DE MELLO, J. M. CLEMENTE, E. JENSEN, T. L. LAURIDSEN \& E. JEPPESEN. 2007. Effects of habitat complexity on community structure and 
predator avoidance behaviour of littoral zooplankton in temperate versus subtropical shallow lakes. Freshwater Biology, 52: 1009-1021.

MESCHIATTI, A. J. \& M. S. ARCIFA. 2002. Early life stages of fish and the relationships with zooplankton in a tropical Brazilian reservoir: Lake Monte Alegre. Brazilian Journal of Biology, 62: $41-50$.

MINTO, W. J., M. S. ARCIFA \& A. PERTICARRARI. 2010. Experiments on the influence of Chaoborus brasiliensis Theobald, 1901 (Diptera: Chaoboridae) on the diel vertical migration of microcrustaceans from Lake Monte Alegre. Brazilian Journal of Biology, 70: 25-35.

OHMAN, M. D. 1990. The demographic benefits of diel vertical migration by zooplankton. Ecological Monographs, 60: 257-281.

PENNAK, W. R. 1943. An effective method of diagramming diurnal movements of zooplankton organisms. Ecology, 24: 405-407.

PERTICARRARI, A., M. S. ARCIFA \& R. A. RODRIGUES. 2003. Diel vertical migration of cladocerans in a tropical lake. Nauplius, 11: 15-25.

PERTICARRARI, A., M. S. ARCIFA \& R. A. RODRIGUES. 2004. Diel vertical migration of copepods in a Brazilian lake: a mechanism for decreasing risk of Chaoborus predation? Brazilian Journal of Biology, 64: 289-298.

REICHWALDT, E. S., I. D. WOLF \& H. STIBOR. 2005. Effects of a fluctuating temperature regime experienced by Daphnia during vertical migration on Daphnia life history parameters. Hydrobiologia, 543: 199-205.

REYNOLDS, C. S. 1984. The ecology of freshwater phytoplankton. Cambridge University Press, Cambridge, UK.

RIESSEN, H. P. 1980. Diel vertical migration of pelagic water mites. In: Evolution and ecology of zooplankton communities. W. C. Kerfoot (ed.): 129-137. The University Press of New England, Hanover, USA.

SMILEY, E. A. \& A. J. TESSIER. 1998. Environmental gradients and the horizontal distribution of microcrustaceans in lakes. Freshwater Biology, 39:
397-409.

SOUZA, B. B. 2015. Variação espacial e temporal de microcrustáceos planctônicos do lago Monte Alegre e experimentos abordando a influência da qualidade do alimento sobre o desempenho dos cladóceros. Master's Thesis. Universidade de São Paulo, Brasil.

TAVŞANOĞLU, Ü. N., A. I. CAKIROĞLU, S. ERDOĞAN, M. MEERHOFF, E. JEPPESEN \& M. BEKLIOĞLU. 2012. Sediments, not plants, offer the preferred refuge for Daphnia against fish predation in Mediterranean shallow lakes: an experimental demonstration. Freshwater Biology, 57: 795-802.

TAVŞANOĞLU, Ü. N., S. BRUCET, E. E. LEVI, T. BUCAK, G. BEZIRCI, A. ÖZEN, L. S. JOHANSSON, E. JEPPESEN \& M. BEKLIOĞLU. 2015. Size-based diel migration of zooplankton in Mediterranean shallow lakes assessed from in situ experiments with artificial plants. Hydrobiologia, 753: 47-59.

TEIXEIRA-DE MELLO, F., M. MEERHOFF, Z. PEKCAN-HEKIM \& E. JEPPESEN. 2009. Substantial differences in littoral fish community structure and dynamics in subtropical and temperate shallow lakes. Freshwater Biology, 54: 1202-1215.

WILLIAMSON, C. E. \& M. E. STOECKEL. 1990. Estimating predation risk in zooplankton communities: the importance of vertical overlap. Hydrobiologia, 198: 125-131.

WILLIAMSON, C. E., J. M. FISCHER, S. M. BOLLENS, E. P. OVERHOLT \& J. K. BRECKENRIDGE. 2011. Toward a more comprehensive theory of zooplankton diel vertical migration: Integrating ultraviolet radiation and water transparency into the biotic paradigm. Limnology and Oceanography, 56: 1603-1623.

WOJTAL-FRANKIEWICZ, A., P. FRANKIEWICZ, P. JURCZAK, J. GRENNAN \& T. K. MCCARTHY. 2010. Comparison of fish and phantom midge influence on cladocerans diel vertical migration in a dual basin lake. Aquatic Ecology, 44: 243-254. 